\title{
CROSS-TOLERANCE OF CALLUS LINES OF WINTER TRITICALE TO COMPLEX OF ABIOTIC STRESSORS
}

\section{Pykalo S.V.}

The V.M. Remeslo Myronivka Institute of Wheat of NAAS, Ukraine

The level of cross-tolerance of triticale callus lines obtained both to salt and osmotic stress was analyzed. It was established that stability of expression of the character in callus lines obtained was rather high - of 50 to $76 \%$ calli survived to the end of the sixth passage. Salt- and osmotolerant callus lines of triticale demonstrated actively their growth on selective medium with sublethal concentrations of mannitol and sodium chloride respectively. Triticale salt-tolerant cell lines were characterized with high content of free proline too.

Key words: Triticale, salt stress, osmotic stress, tolerance, free proline, callus lines

Introduction. Creation of triticale varieties which are successfully introduced in agricultural production [1] is a major achievement of modern genetics and plant breeding. However, despite the high potential opportunities this evolutionary young crop has not yet received widespread industrial use [2]. Not enough high plasticity of triticale varieties and breeding forms associated with limited genetic diversity of source material needs to improve by means of enriching the gene pool of the crop and increasing efficiency of breeding with various methods [3].

Being important for triticale breeding improvement, tolerance to abiotic stressful environmental factors, including drought and soil salinization will encourage expanding the crop areas in regions with unfavorable climatic conditions [4-6]. Drought causes water deficit in soil and thereafter in plants, thus being a reason for osmotic stress in them [7]. The harmful effect of salinity is of complex nature and is due to both breach of osmotic balance in cells and direct toxic effects on cell physiological and biochemical processes $[8,9]$. Often plants are exposed simultaneously to multiple stressors, and their negative impact is greatly enhanced [10]. So, we need plants that can not only endure adverse conditions, but also actively resist to them, viz. function under stressful conditions. Solving the problem of stress tolerance requires the development of new biotechnological approaches. One of them is cell 
selection, i.e. selection of genotypes with desirable new hereditary characters at in vitro cultured cells level in specific conditions [11]. Due to using biotechnological methods, it is possible to obtain new forms with desirable characteristics, including specific changes of appropriate metabolic processes to keep plant adaptation in stress conditions [12]. Today, the development of methods of triticale cell selection is only initially, because only a few works on in vitro selection of resistant to stress forms can be found [13-15].

Analysis of literature, formulation of the problem. According to some authors [16-18], the formation of complex plant tolerance to abiotic stresses (salt, osmotic, temperature) at the cellular and tissue level has some similar mechanisms. Selected cell lines and regenerated plant may exhibit tolerance to two or more types of stress that sometimes does not even similar in physical and chemical nature and direction of action. It was shown [19-22] that increase in osmotolerance at the cellular level can provide the whole plant tolerance to multiple abiotic stresses causing cell dehydration. The results give evidence that cell adaptation to osmotic stress can be applied to select salt-tolerant lines or the reverse, and such studies are of interest.

The purpose of the research. To analyze the level of cross-tolerance of salt- and drought-tolerant callus lines of winter triticale both to osmotic and salt stresses.

Material and methods. Carrying the genomes of three species hexaploid winter triticale forms bred at Myronivka, namely Line 38/1296 and cultivar Obrii Myronivskyi that are characterized by high agronomic traits were studied. Callus lines of these genotypes were obtained in our previous studies [23] by cell selection for tolerance to salt $(0.6-1.2 \% \mathrm{NaCl})$ and osmotic $(0.2-0.6 \mathrm{M}$ mannitol) stresses according to the scheme (Fig. 1).

Analysis of cross-tolerance of triticale osmotolerant callus lines to salinity was carried out according to the scheme: selective medium with $1.2 \% \mathrm{NaCl}$ (2 passages) $\rightarrow$ Murashige and Skoog (MS) medium [24] (2 passages) $\rightarrow$ selective medium with $1.2 \% \mathrm{NaCl}$ ( 2 passages). Analysis of cross-tolerance to salt-tolerant callus lines osmotic stress was conducted along similar lines: selective medium with $0.6 \mathrm{M}$ mannitol (2 passages) $\rightarrow$ MS medium (2 passages) $\rightarrow$ selective medium with $0.6 \mathrm{M}$ mannitol (2 passages).

Tolerance of callus cultures to ionic and osmotic stresses was assessed by their survival, wet weight growth and free proline content. The last was determined by a modified Chinard's method [25]. MS medium free of stress factor was as the control. The experimental data obtained were processed with the methods of statistical analysis [26]. 


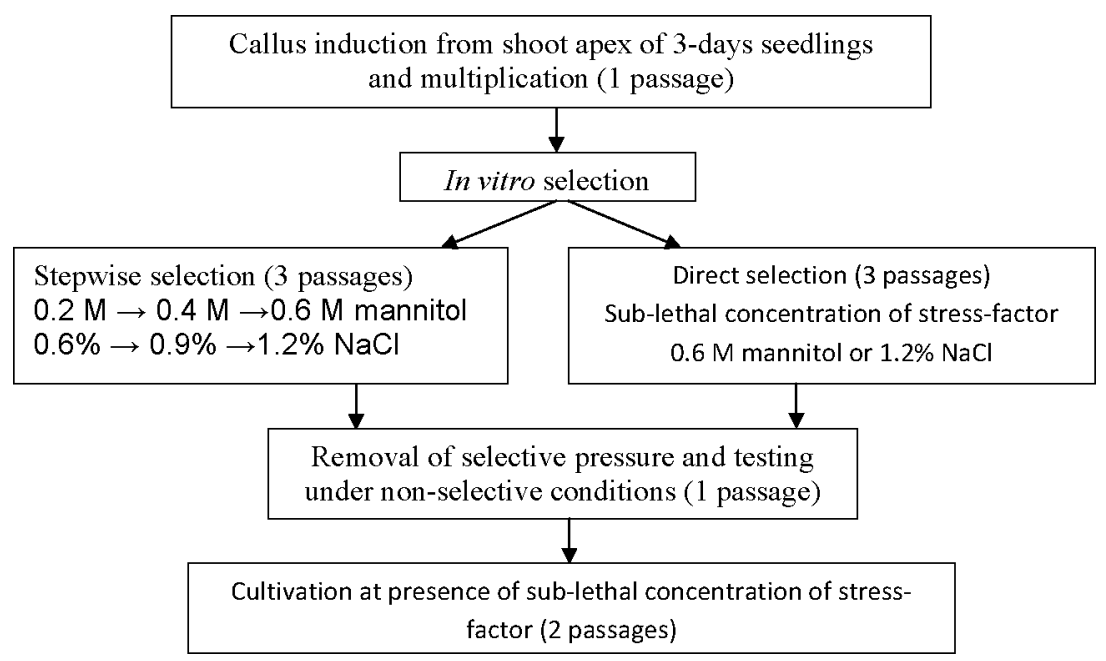

Fig. 1. Scheme of obtaining osmo- and salt-tolerant triticale callus lines

Results and discussion. It is established that stability of expression of cross-tolerance to salt stress lines derived was high enough - to the end of the sixth passage of 51 to $75 \%$ calli survived (Fig. 2).

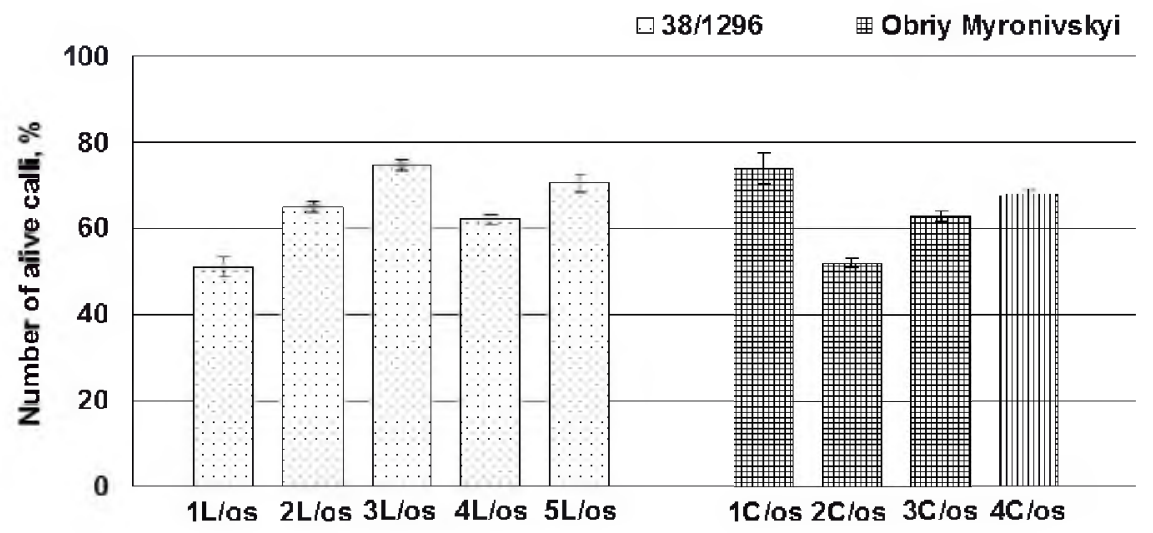

Fig. 2. Survivability of osmotic stress tolerant triticale callus lines following 6 passages in selective $(1.2 \% \mathrm{NaCl})$ medium:

$1 \mathrm{~L} / \mathrm{os}-5 \mathrm{~L} / \mathrm{os}$ and $1 \mathrm{C} / \mathrm{os}-4 \mathrm{C} / \mathrm{os}$ - osmotic stress tolerant callus lines

$110 \frac{\text { Миронівський вісник }}{\text { Випуск 3,2016 }}$ 
When determining the crude weight increment, resistant callus were revealed to continue growth despite the presence of sublethal concentrations of $\mathrm{NaCl}$ in selective medium (Fig. 3).

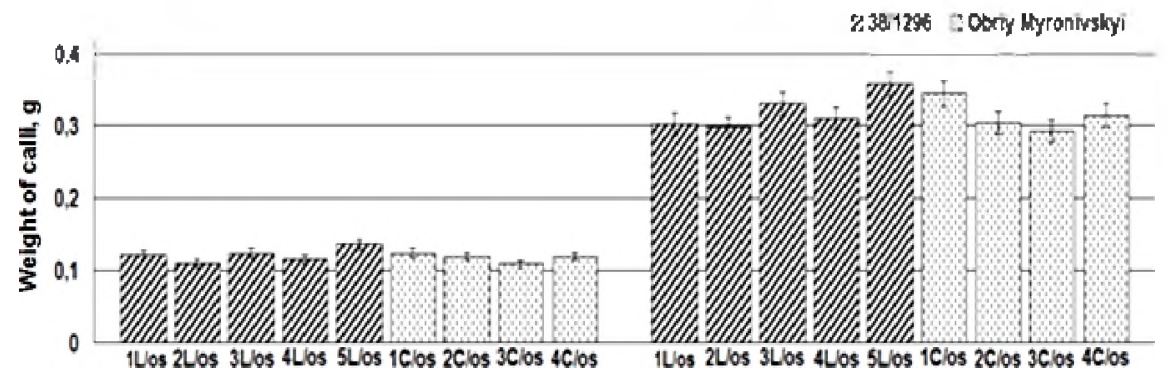

Fig. 3. Crude weight increment of osmotic stress tolerant triticale callus lines following 6 passages in selective $(1.2 \% \mathrm{NaCl})$ medium: $1 \mathrm{~L} / \mathrm{os}-5 \mathrm{~L} / \mathrm{os}$ and $1 \mathrm{C} / \mathrm{os}-4 \mathrm{C} / \mathrm{os}-$ osmotic stress tolerant callus lines

In general, tolerant cell lines 3L/os and 5L/ derived from the Line 38/1296, as well as lines $1 \mathrm{C} /$ os and $4 \mathrm{C} /$ os derived from the variety Obrii Myronivskyi should be identified, whereas they were characterized by the highest proportion of alive calli and kept the ability to increase biomass in selective conditions. Cell lines with cross-tolerance were distinguished with following morphological characteristics: compact dark yellow callus of globular structure (Fig. 4).

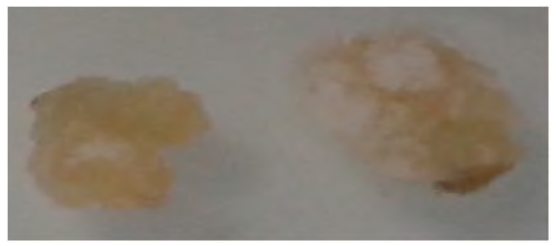

Fig. 4. Osmotic stress tolerant triticale calli on selective medium supplemented with $1.2 \% \mathrm{NaCl}$ at the end of the 6-th passage

Thus, the data obtained indicate sufficiently high cross-resistance of osmotic stress tolerant cell lines to salt stress as well.

Based on the existence of both specific and general system of tolerance [16-22], we also analyzed cross-tolerance of salt-tolerant callus lines to osmotic stress. For this, they were cultured for 6 passages by scheme: selective medium with $0.6 \mathrm{M}$ mannitol (2 passages) $\rightarrow$ MS medium ( 2 passages) $\rightarrow$ selective medium with $0.6 \mathrm{M}$ mannitol ( 2 passages). As in previous studies, tolerance of cell cultures to osmotic stress was assessed by survival and growth of wet weight (Fig. 5, 6). 


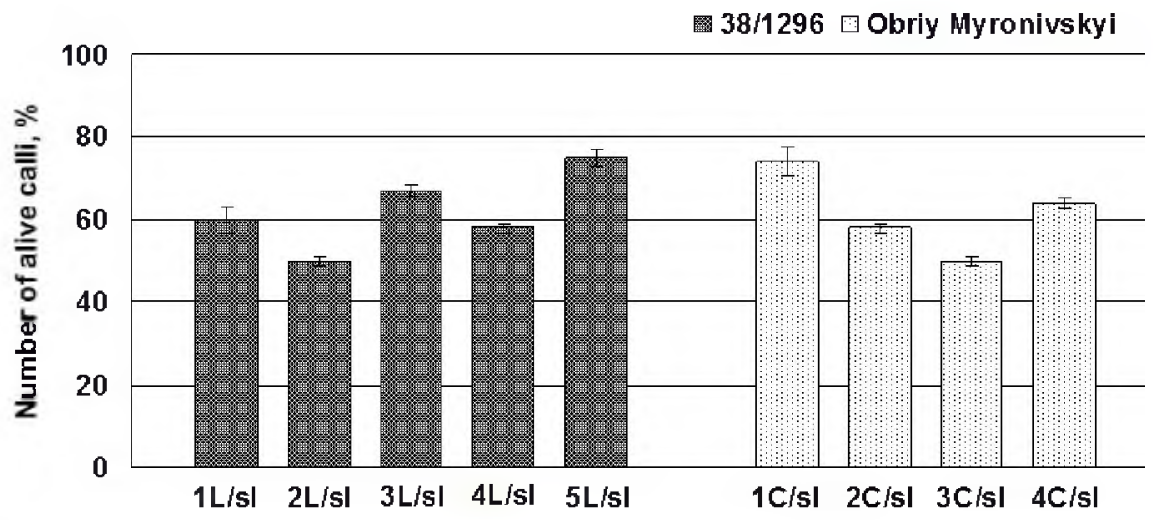

Fig. 5. Survivability of salt stress tolerant triticale callus lines following 6 passages in selective $(0.6 \mathrm{M}$ mannitol) medium: $1 \mathrm{~L} / \mathrm{sl}-5 \mathrm{~L} / \mathrm{sl}$ and $1 \mathrm{C} / \mathrm{sl}-4 \mathrm{C} / \mathrm{sl}-$ salt stress tolerant callus lines

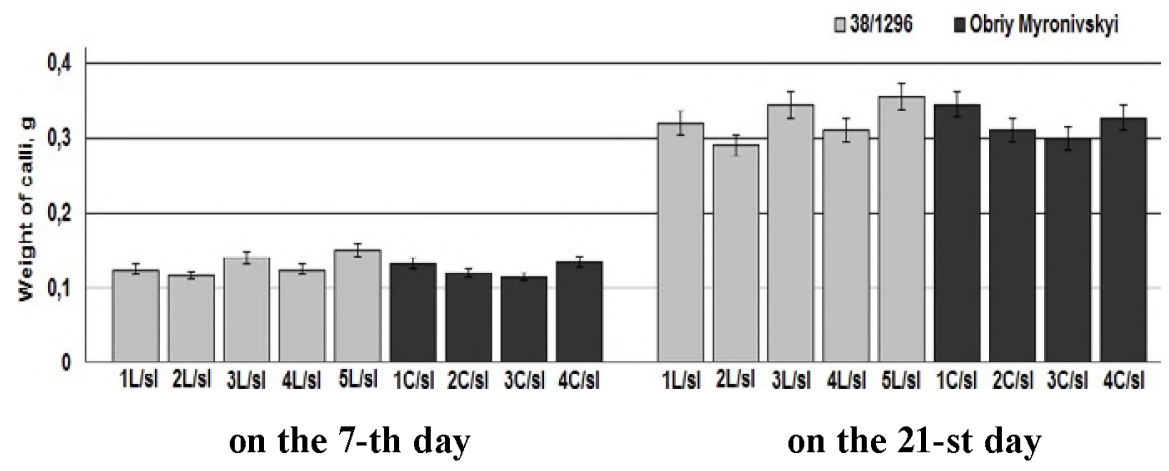

Fig. 6. Crude weight increment of salt stress tolerant triticale callus lines following 6 passages in selective $(0.6 \mathrm{M}$ mannitol) medium: $1 \mathrm{~L} / \mathrm{sl}-5 \mathrm{~L} / \mathrm{sl}$ and $1 \mathrm{C} / \mathrm{sl}-4 \mathrm{C} / \mathrm{sl}$ - salt stress tolerant callus lines

During the research we found that the stability of expression of crosstolerance to osmotic stress in cell lines obtained was at high enough level - by the end of the sixth passage of 50 to $76 \%$ calli survived. It was also shown that, even in the presence of sublethal concentrations of mannitol in selective medium resistant calli actively continued to increase biomass. 
We also determined free proline content in callus lines investigated. It was established that salt-tolerant cell lines of both triticale genotypes were characterized by high free proline content (Fig. 7).

It should be emphasized that the callus lines $3 \mathrm{~L} / \mathrm{sl}$ and $5 \mathrm{~L} / \mathrm{sl}$ derived from the Line 38/1296 had the highest proline content as well as the lines 1C/sl and $4 \mathrm{C} / \mathrm{sl}$ derived from the cultivar Obrii Myronivskyi were distinguished for this index. The data obtained are proof of the increased tolerance to osmotic stress in the triticale callus lines analyzed.
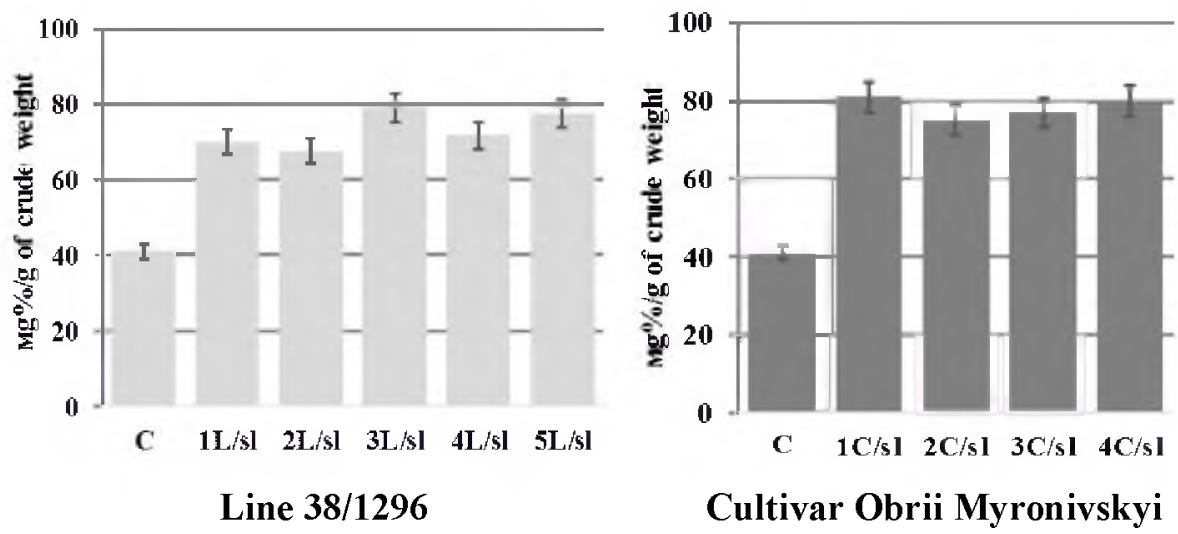

Fig. 7. Free proline level in salt stress tolerant triticale callus lines (C - control; $1 \mathrm{~L} / \mathrm{sl}-5 \mathrm{~L} / \mathrm{sl}$ and $1 \mathrm{C} / \mathrm{sl}-4 \mathrm{C} / \mathrm{sl}$ - salt stress tolerant callus lines)

Sergeeva L.E. et al. [27] have used this index also when analyzing crossresistance to osmotic stress in Cd-tolerant tobacco cell lines and regenerated plants. Tobacco cell lines being resistant to cadmium cations and regenerated plants derived from them were analyzed in simulated water stress conditions in vitro, when using low molecular mannitol as selective agent. The authors have shown that proline content in tolerant lines was significantly higher than in the wild type; increased content was observed in cells of both calli and leaves. The researches imply proline participation in osmotic regulation of Cd-tolerant tobacco lines and regenerated plants when cultivating in vitro under conditions of osmotic stress. It was revealed cross-tolerance in tobacco cell lines obtained as to osmotic stress, as well as to cadmium ions.

Proline is known to be one of the most multifunctional stress metabolites in plants. Several authors [27-29] in their works indicated that, along with well- 
known proline function as inert compatible osmolyte, under actions of abiotic stressors it also carries out a number of other interrelated functions serving as membrane protector, chaperone, and antioxidant and is involved in regulation of expression for certain genes. Just under stressful conditions this amino acid exhibits its properties mentioned above. Therefore, even a slight change in its concentration can affect the viability of plants under stress conditions.

Thus, as a result of consistent work we have found cross-tolerance of triticale callus lines obtained as to salt and osmotic stresses. Earlier T.V. Chugunkova [30] by methods of cell selection on selective media added by sodium sulphate and sodium chloride has obtained callus line of sugar and fodder beet resistant to both the individual and the complex stress factors, including toxin of bacteriosis pathogen, low positive temperature as well as one type of salinity -chloride or sulfate. Test for stability of tolerance to the complex of stress factors proved the tolerance of most beet callus lines and regenerated plant derived from them. Increased salt tolerance was found in wheat regenerated plants induced from osmotic (mannitol) tolerant cell lines [19]. In selective system with PEG salt-tolerant rice clones were obtained [22]. Among corn plants regenerated from mannitol tolerant callus the forms with increased tolerance not only to water deficit, but also to salinity, low positive and negative temperatures were selected [20]. The authors explain it to the fact that due to general non-specific mechanisms of tolerance the resistance to alone adverse factor may lead to increase to the other one.

Conclusions. Test of tolerance to abiotic stressors showed high enough level of cross-tolerance of triticale callus lines obtained as to salt and to osmotic stresses. It is shown that in the presence of sublethal concentrations of the stress-factor in selective medium tolerant calli kept accumulating biomass actively. Triticale salt-tolerant cell lines were characterized also with high free proline content. In prospect it is necessary to test maintenance of tolerance in regenerated plants and their seed generations.

\section{Список використаних джерел}

1. Oettler G. The fortune of a botanical curiosity - Triticale: past, present and future / G. Oettler // J. Agric. Sci. - 2005. - Vol. 143, N 5. - P. 329-346.

2. Агрономічний потенціал і перспективи тритикале / [О.І. Рибалка, В.В. Моргун, Б.В. Моргун, В.М. Починок] // Физиология растений и генетика. - 2015. - Т. 47, № 2. - С. 95-111.

3. Kavanagh V.B. Potential hybridization of genetically engineered triticale with wild and weedy relatives in Canada/ V.B. Kavanagh, J.C. Hall, L.M. Hall // Crop Sci. - 2010. - Vol. 50. - P. 1128-1140. 
4. Blum A. The abiotic stress response and adaptation of triticale - a review / A. Blum // Cereal Res. Commun. - 2014. - Vol. 42, N 3. - P. 359-375.

5. Орловская О.А. Оценка устойчивости к биотическим и абиотическим факторам гибридов озимой тритикале, созданных на основе образцов различного эколого-географического происхождения / О.А. Орловская, Л.В. Хотылева // Молекулярная и прикладная генетика: Сб. науч. тр. / Институт генетики и цитологии НАН Беларуси. - Мн., 2013. - Т. 14. - С. 77-83.

6. Авдеев Ю.И. Устойчивость озимой тритикале к экстремальным абиотическим факторам среды в аридной зоне возделывания / Ю.И. Авдеев, Л.А. Слащева // Астраханский вестник экологического образования. - 2014. - Т. 29, № 3. - С. 84-87.

7. Blum A. Drought resistance, water-use efficiency, and yield potential - are they compatible, dissonant, or mutually exclusive? / A. Blum // Austr. J. Agric. Res. - 2005. - Vol. 56, N 11. - P. 1159-1168.

8. Krasensky J. Drought, salt, and temperature stress-induced metabolic rearrangements and regulatory networks / J. Krasensky, C. Jonak // J. Exp. Bot. - 2012. - Vol. 63, N 4. - P. 1593-1608.

9. Bartels D. Drought and salt tolerance in plants / D. Bartels, R. Sunkar // Crit. Rev. Plant Sci. - 2005. - Vol. 24, N 1. - P. 23-58.

10. Zhu J.-K. Salt and drought stress signal transduction in plants / J.-K. Zhu // Ann. Rev. Plant Biol. - 2002. - Vol. 53. - P. 247-273.

11. Дубровна О.В. Клітинна селекція пшениці на стійкість до стресових чинників довкілля / О.В. Дубровна, Б.В. Моргун // Физиология и биохимия культ. растений. - 2009. - Т. 41, № 6. - С. 463-475.

12. Решетников В.Н. Биотехнология растений и перспективы ее развития / В.Н. Решетников, Е.В. Спиридович, А.М. Носов // Физиология растений и генетика. -2014 . - Т. 46, № 1. - С. 3-18.

13. Cheng-he $Z$. Selection and characterization of high $\mathrm{pH}$ resistant or salt resistant variants from haploid Triticale callus $(n=28) / Z$. Cheng-he, C. Jun, B. Wen-kui // Acta Bot. Sin. - 1986. - Vol. 28. - P. 137-144.

14. ShouXi C. Effects of Fusarium metabolites on growth of callus and seedling in triticale / C. ShouXi, G. Kleijer // Acta Prataculturae Sin. 2001. - Vol. 10. - P. 78-85.

15. Селекция in vitro культурных сортов гороха и тритикале на устойчивость к абиотическим стрессам / [К.К. Абдрашева, Д.С. Тагиманова, О.Н. Хапилина, Ж.С. Купешев] // Биология - наука XXI века: 19-я Международная Пущинская школа-конференция молодых ученых, 20-24 апреля 2015 г. - Пущино, 2015. - С. 3-4. 
16. Шакирова Ф.М. Неспецифическая устойчивость растений к стрессовым факторам и ее регуляция / Ф.М. Шакирова. - Уфа: Гилем, 2001. - $160 \mathrm{c}$.

17. Соловьян В.Т. Приспособление клеток к неблагоприятным факторам. Характеристика адаптивных ответов / В.Т. Соловьян // Биополимеры и клетка. - 1990. - Т. 6, № 4. - С. 32-42.

18. Губанова Н.Я. Клеточная селекция кормовой свеклы на устойчивость к нескольким стрессовым факторам / Н.Я. Губанова, О.В. Дубровная, Т.В. Чугункова // Биополимеры и клетка. - 2002. T.18, № 3.- C. 227-231.

19. Levenko B.A. Selection for resistance to water and salt stress in wheat / B.A. Levenko, E.Yu. Pasternak, N.V. Sidorova // Abstr. VII Intern. Congr. Plant Tissue and Cell Culture. - Amsterdam, 1990. - P. 37.

20. Аль-Холани Х.А.М. Получение стресс-толерантных растений кукурузы методом клеточной селекции: Автореф. дис. ... канд. биол. наук: спец. 03.01.05 "Физиология и биохимия растений" / Х.А.М. Аль-Холани; Институт физиологии растений им. К.А. Тимирязева РАН - М., 2010. -24 c.

21. Зінченко М.О. Клітинна селекція пшениці на стійкість до комплексу стресових факторів: Автореф. дис. ... канд. біол. наук: спец. 03.00.15. "Генетика" / М.О. Зінченко; Ін-т фізіології рослин і генетики НАНУ. - K., 2014. - $20 \mathrm{c}$.

22. Белянская С.Л. Получение и характеристика клонов риса, резистентных к стрессовым факторам / С.Л. Белянская, 3.Б. Шамина // Физиология растений. - 1993. - Т. 40, № 4. - С. 681-685.

23. Селекція in vitro тритикале озимого на стійкість до водного дефіциту / [С.В. Пикало, М.О. Зінченко, С.І. Волощук, О.В. Дубровна] // Biotechnologia Acta. - 2015. - T. 8, № 2. - C. 69-77.

24. Murashige T. A revised medium for rapid growth and bioassay with tobacco tissue cultures / T. Murashige, F. Skoog // Physiol. Plant. - 1962. Vol. 15, N 3. - P. 473-497.

25. Андрющенко В.К. Модификация метода определения пролина для выявления засухоустойчивых форм рода Lycopersicon Tourn / В.К. Андрющенко, В.В. Саянова, А.А. Жученко // Изв. Акад. наук Молд. ССР. - 1981. - Т. 4. - С. 55-60.

26. Лакин Г.Ф. Биометрия / Г.Ф. Лакин. - М.: Высшая школа, 1990. -352 c.

27. Сергеева Л.Е. Содержание свободного пролина как показатель жизнедеятельности клеточной культуры Nicotiana tabacum L. при стрессе / Л.Е. Сергеева, Л.И. Бронникова, Е.Н. Тищенко // Біотехнологія. - 2011. - Т. 4, № 4. - С. 87-94.

116 Миронівський вісник

Випуск 3, 2016 
28. Szabados L. Proline: a multifunctional amino acid / L. Szabados, A. Savoure // Trends Plant Sci. - 2009. - Vol. 15, N 2. - P. 89-97.

29. Колупаев Ю.Е. Пролин: физиологические функции и регуляция содержания в растениях в стрессовых условиях / Ю.Е. Колупаев, А.А. Вайнер, Т.О. Ястреб // Вісник Харківського національного аграрного університету. Серія Біологія. - 2014. - Вип. 2(32). - С. 6-22.

30. Чугункова Т.В. Використання клітинної селекції для створення стійких форм буряків / Т.В. Чугункова // Физиология и биохимия культ. растений. - 2009. - Т. 41, № 6. - С. 509-515.

\section{References}

1. Oettler G. The fortune of a botanical curiosity - Triticale: past, present and future. J. Agric. Sci. 2005; 143(5): 329-346.

2. Rybalka OI, Morgun VV, Morgun BV, Pochynok VM. Agronomic potential and perspectives of triticale. Fiziologiya Rastenii i Genetika Plant Physiology and Genetics. 2015; 47(2): 95-111.

3. Kavanagh VB, Hall JC, Hall LM. Potential hybridization of genetically engineered triticale with wild and weedy relatives in Canada. Crop Sci. 2010; 50: 1128-1140.

4. Blum A. The abiotic stress response and adaptation of triticale - a review. Cereal Res. Commun. 2014; 42(3): 359-375.

5. Orlovskaya OA, Khotylyova LV. Assessment for resistance to biotic and abiotic factors of winter triticale hybrids created on the basis of samples of different ecological and geographical origin. Molekulyarnaya i Prilkadnaya Genetica - Molecular and Applied Genetics: Collected Works. Institute of Genetics and Cytology of NAS of Belarus. Minsk. 2013; 14 : 77-83.

6. Avdeev YuI, Slashcheva LA. Stability of winter Triticale to extreme abiotic factors of the environment in the arid zone of cultivation. Astrakhanskiy Vestnik Ekologicheskogo Obrazovaniya - Astrakhan Bulletin of Ecological Education. 2014: 29(3): 84-87.

7. Blum A. Drought resistance, water-use efficiency, and yield potential - are they compatible, dissonant, or mutually exclusive? Austr. J. Agric. Res. 2005; 56(11): 1159-1168.

8. Krasensky J, Jonak C. Drought, salt, and temperature stress-induced metabolic rearrangements and regulatory networks. J. Exp. Bot. 2012; 63(4): P. 1593-1608.

9. Bartels D, Sunkar R. Drought and salt tolerance in plants. Crit. Rev. Plant Sci. 2005; 24(1): 23-58. 
10. Zhu J-K. Salt and drought stress signal transduction in plants. Ann. Rev. Plant Biol. 2002; 53: 247-273.

11. Dubrovna OV, Morgun BV. Cellular selection of wheat for resistance to stress factors of environment. Fiziologiia i Biokhimiia Kul'turnykh Rastrenii - Physiology and Biochemistry of Cultivated Plants. 2009; 41(6): 463-475.

12. Reshetnikov VN, Spiridovich EV, Nosov AM. Plant biotechnology and perspectives of its development. Fiziologiya Rastenii i Genetika - Plant Physiology and Genetics. 2014; 46(1): 3-18.

13. Cheng-he Z, Jun C, Wen-kui B. Selection and characterization of high $\mathrm{pH}$ resistant or salt resistant variants from haploid Triticale callus $(n=28)$. Acta Bot. Sin. 1986; 28: 137-144.

14. ShouXi C, Kleijer G. Effects of Fusarium metabolites on growth of callus and seedling in triticale. Acta Prataculturae Sin. 2001; 10: 78-85.

15. Abdrasheva KK, Tagimanova DS, Khapilina ON, Kupeshev ZhS. Selection in vitro of pea and Triticale cultivars for resistance to abiotic stresses. Biology - the Science of the XXI Century: the 19th International Pushchino School Conference of Young Scientists. Pushchino; 2015. P 3-4.

16. Shakirova FM. Non-specific Plant Resistance to Stress Factors and its Regulation. Ufa: Gilem; 2001. 160 p.

17. Solovyan VT. Adaptation of cells to environmental factors. Characteristic of adaptive responses. Biopolimery i Kletka - Biopolimers and Cell. 1990; 6(4): 32-42.

18. Gubanova NYa, Dubrovnaya OV, Chugunkova TV. The cell breeding of mangel beet resistant to several stress factors. Biopolimery i Kletka Biopolimers and Cell. 2002; 18(3): 227-231.

19. Levenko BA, Pasternak EYu, Sidorova NV. Selection for resistance to water and salt stress in wheats. Abstr. VII Intern. Congr. Plant Tissue and Cell Culture. Amsterdam; 1990. P. 37.

20. Al-Kholani KhAM. Obtaining stress-tolerant maize plants by cellular selection. Thesis Abstract for Candidate of Science (Biology): 03.01.05. Moscow; 2010. 24 p.

21. Zinchenko MO. In vitro selection of wheat for resistance to complex stressors. Thesis Abstract for Candidate of Science (Biology): 03.00.15. Kyiv; 2014. 20 p.

22. Belyanskaya SL, Shamina ZB. Obtaining and characteristics of rice clones resistant to stress factors. Fiziologiya Rasteniy - Russian Journal of Plant Physiology. 1993; 40(4): 681-685.

23. Pykalo SV, Zinchenko MO, Voloshchuk SI, Dubrovna OV. In vitro 
selection of winter triticale for the resistance to water deficit. Biotechnologia Acta. 2015; 8(2): 69-77.

24. Murashige T, Skoog F. A revised medium for rapid growth and bioassay with tobacco tissue cultures. Physiol. Plant. 1962; 15(3): 473-497.

25. Andryushchenko VK, Sayanova VV, Zhuchenko AA, Modification of proline determination method for identification Lycopersicon Tourn drought-resistant forms. Izvestiya Akademii Nauk Moldavskoy SSR News of Academy of Sciences of Moldova SSR. 1981; 4: 55-60.

26. Lakin GF. Biometry. Moscow: Vysshaya Shkola; 1990. 352 p.

27. Sergeeva LE, Bronnikova LI, Tishchenko EN. The free proline content as the viability index of Nicotiana tabacum L. cell culture under stress conditions. Biotechnology. 2011; 4(4): 87-94.

28. Szabados L, Savoure A. Proline: a multifunctional amino acid. Trends Plant Sci. 2009; 15(2): 89-97.

29. Kolupayev YuE, Vayner AA, Yastreb TO. Proline: physiological functions and regulation of its content in plants under stress conditions. Visnyk Kharkivskoho Natsionalnoho Agrarnoho Universytetu - The Bulletin of Kharkiv National Agrarian University. 2014; 2: 6-22.

30. Chugunkova TV. The using of cell selection for creation of resistant forms of beet. Fiziologiia i Biokhimiia Kul'turnykh Rastrenii - Physiology and Biochemistry of Cultivated Plants. 2009; 41(6): 509-515.

\section{ПЕРЕХРЕСНА СТІЙКІСТЬ КАЛЮСНИХ ЛІНІЙ ТРИТИКАЛЕ ОЗИМОГО ДО КОМПЛЕКСУ АБІОТИЧНИХ СТРЕСОРІВ}

\section{Пикало С.В.}

Миронівський інститут пшениці імені В.М. Ремесла НААН, Україна

Мета. Проаналізувати рівень перехресної стійкості отриманих солеі осмостійких калюсних ліній тритикале озимого як до осмотичного, так $\mathrm{i}$ до сольового стресів.

Матеріал і методика. Матеріалом досліджень були форми тривидового гексаплоїдного тритикале озимого миронівської селекції Лінія 38/1296 i сорт Обрій Миронівський. Використовували методи культури тканин iз застосуванням селективних систем з манітом і хлоридом натрію.

Результати. Встановлено, що стабільність прояву ознаки перехресної стійкості до сольового і осмотичного стресів у отриманих клітинних ліній 
була досить високою - до кінця шостого пасажу виживало від 50 до 76\% калюсів. Показано, що при наявності в селективному середовищі сублетальної концентрації стрес-фактора стійкі калюси активно продовжували накопичувати біомасу. Солестійкі клітинні лінії обох генотипів характеризувалися також підвищеним вмістом вільного проліну.

Висновки. Оцінка стійкості до абіотичних стресорів свідчить про достатньо високий рівень перехресної толерантності отриманих калюсних ліній тритикале як до сольового, так і до осмотичного стресів. У подальшому необхідно перевірити збереження стійкості в рослинах-регенерантах та їх насінневих поколіннях.

Ключові слова: Triticale, сольовий стрес, осмотичний стрес, стійкість, вільний пролін, калюсні ліній

\section{ПЕРЕКРЕСТНАЯ УСТОЙЧИВОСТЬ КАЛЛУСНЫХ ЛИНИЙ ТРИТИКАЛЕ ОЗИМОГО К КОМПЛЕКСУ АБИОТИЧЕСКИХ СТРЕССОРОВ}

\section{Пыкало С.В.}

Мироновский институт пшеницы имени В.Н. Ремесло НААН, Украина

Цель. Проанализировать уровень перекрестной устойчивости полученных соле- и осмоустойчивых каллусных линий тритикале озимого как к осмотическому, так и к солевому стрессам.

Материал и методика. Материалом для исследований были формы трехвидовых гексаплоидных тритикале озимого мироновской селекции Линия 38/1296 и сорт Обрій Миронівський. Использовали методы культуры тканей с применением селективных систем с маннитом и хлоридом натрия.

Результаты. Установлено, что стабильность проявления признака перекрестной устойчивости к солевому и осмотическому стрессам у полученных клеточных линий была достаточно высокой - к концу шестого пассажа выживало от 50 до 76\% каллусов. Показано, что при наличии в селективной среде сублетальной концентрации стрессфактора устойчивые каллусы активно продолжали накапливать биомассу. Солеустойчивые клеточные линии обоих генотипов характеризовались также повышенным содержанием свободного пролина.

Выводы. Оценка устойчивости к абиотическим стрессорам свидетельствует о достаточно высоком уровне перекрестной толерантности 
полученных каллусных линий тритикале как к солевому, так и к осмотическому стрессам. В дальнейшем необходима проверка сохранения устойчивости в растениях-регенерантах и их семенных поколениях.

Ключевые слова: Triticale, солевой стресс, осмотический стресс, устойчивость, свободный пролин, каллуснье линии

\section{CROSS-TOLERANCE OF CALLUS LINES OF WINTER TRITICALE TO COMPLEX OF ABIOTIC STRESSORS}

\section{Pykalo S.V.}

The V.M. Remeslo Myronivka Institute of Wheat of NAAS, Ukraine

Aim. To analyze the level of cross-tolerance of salt- and drought-tolerant callus lines of winter triticale both to osmotic and salt stresses.

Methods. Forms of three-species hexaploid winter triticale bred at Myronivka Line 38/1296 and variety Obrii Myronivskyi were studied. Tissue culture methods with application of selective systems based on mannitol and sodium chloride were used.

Results. It was established that the stability of performance of cross-tolerance to salt and osmotic stress in callus lines obtained was sufficiently high - of 50 to $76 \%$ calli survived to the end of the sixth passage. It was shown that in the presence of sublethal concentrations of the stress-factors in selective medium tolerant calli actively continued to accumulate biomass. The salt-tolerant cell lines of both genotypes were characterized also high free proline content.

Conclusions. Estimation of tolerance to abiotic stressors demonstrated high enough level of cross-tolerance of Triticale callus lines obtained for both salt and osmotic stresses. In prospect it is necessary to test maintenance of tolerance in regenerated plants and their seed generations.

Key words: Triticale, salt stress, osmotic stress, tolerance, free proline, callus lines 